\title{
Adding Ginger Powder or Oil and its Effect on Nutritional Evaluation of Rams Rations
}

\section{M.S. Nassar}

Department of Animal and Poultry Nutrition, Desert Research Center, P.O. Box 11753, El-Matareya, Cairo, Egypt.

\begin{abstract}
The current experiment was carried out in Maryout Research Station, Desert Research Center (DRC) to evaluate the effects of additives ginger powder or oil on, feed intake, digestibility, nitrogen and water utilization, ruminal and blood parameters of Barki sheep. Four Barki rams of each group with an average live weight $(36.37 \pm 0.99 \mathrm{~kg})$ were individually kept and fed in metabolic cages to determine nutrient digestibility and nutritive value of the experimental rations. Feed offered was calculated to cover requirements according to recommended by Kearl (1982) Roughage concentrate ratio was 40:60. The treatments included: (G1) without any additives (Control), The (G2) and (G3) groups were additives (with 3 and 6 gm ginger powder $(G P) / h e a d / d a y)$, respectively. Ginger powder was mixed daily by concentrate mixture to offer for daily basis. The (G4) group was orally administered by (2 ml ginger oil (GO) / head/ day).
\end{abstract}

The data indicated that Values of dry roughage, concentrate intake and total DMI $(\mathrm{g} / \mathrm{kg} \mathrm{BW})$ were insignificant

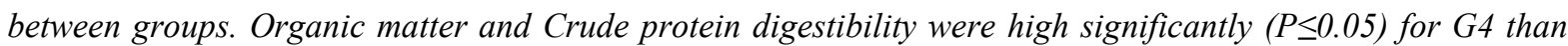
those recorded for ram in G2, G1 and G3 groups. While values insignificantly differences in DM, CF and NDF digestibility between all groups. However, animals fed G4 had high insignificantly digestibility coefficients of $D M$, and $C F$ than other groups. Data of nutritive values indicated that $G 4$ recorded high significantly $(P \leq 0.05)$ TDN, DCP vs. those other group. Rams in G4 group had high significantly $(P \leq 0.05)$ value of TDN\% and $D C P \%$ than other groups. Nitrogen intake $(\mathrm{g} / \mathrm{kg} \mathrm{BW})$ was insignificantly affected by treated with ginger forms. As for digested nitrogen $(\mathrm{g} / \mathrm{kg} \mathrm{BW})$ the data was insignificant among experimental groups, it seems that G4 had the highest values of digested nitrogen, while it was significantly differed with digested nitrogen as a percentage of intake. Nitrogen balance as $((\mathrm{g} / \mathrm{kg} \mathrm{BW})$ or \% of digested) showed that were insignificant between experimental groups; it seems that G4 had the highest while G2 had the lowest values of nitrogen balance. Water balance was slightly difference significantly $(P \leq 0.05)$ among treatments; Glhad the highest values of water balance as $(\mathrm{ml} / \mathrm{Kg} \mathrm{BW})$ followed by G2, G3 while the lowest total water balance was for G4.Data of pH value was within the normal range, Either ruminal $\mathrm{pH}$ levels or TVFA,s (meq/100 ml) concentration were not significantly affected by the experimental additives. Ammonia nitrogen was affected by ginger both powder or oil additives and significantly decreased in groups fed ginger both powder or oil compared with the control group, while G4 take the lowest values than for G2 and G3 which fed with ginger powder additives. With regard to Protozoa number insignificantly decreased in groups fed ginger both powder or oil compared with the control group, while G4 take the lowest values than for G2 and G3 which fed with ginger powder additives. Results of blood biochemical showed that insignificant differences among groups for total proteins and albumin , Total proteins increased in G3 take the highest values than other groups while G4 take the lowest value, G4

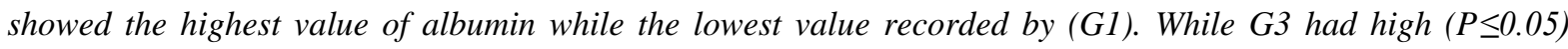
globulin value than other groups. Animals fed ginger either powder or oil additives had high IgG than control group. Total lipids and triglyceride values showed significant $(P \leq 0.05)$ increase in animals $G 4$.Also (G2 and $G 4)$ had high Cholesterol than control group. Serum urea concentration decreased significantly $(P \leq 0.05)$ in $G 4$, while G3 high than other groups. (G1) recorded significant $(P \leq 0.05)$ decrees for creatinine while G4 recorded high value of creatinine than other groups. ALT and AST activity showed that there were significant $(P \leq 0.05)$ decreases for G1 While ALP and GGT decrease insignificant for G1 for other groups. In conclusion,

ISSN: 2456-1878

https://dx.doi.org/10.22161/ijeab.53.30 
International Journal of Environment, Agriculture and Biotechnology, 5(3)

May-Jun, 2020 / Available: https://ijeab.com/

ginger both powder or oil additives to ration of Barki rams had beneficial effects on digestibility coefficients,

Nitrogen and water balance, Ruminal fermentation and some blood biochemical parameters

Keywords - Barki sheep, ginger powder, ginger oil, feed intake, digestibility, rumen liquor and blood
parameters.

\section{INTRODUCTION}

In Egypt, small ruminant and camel constitute the most valuable activities in the northern coastal zone due to their resistance to dry conditions. Livestock, particularly sheep, are of considerable economic importance and it plays an important role for the livelihood of rural household, the contribution of livestock to household income ranges from $50.34 \%$ to $74.3 \%$. Sheep contribute up to $74.56 \%$ of the net cash income derived from livestock production in the rain fed region Bakry et al. (2018). Barki sheep which dominate the north western desert of Egypt with population of 470,000 heads (11\% of the total Egyptian sheep population) are known to be well -adapted to the desert harsh conditions and scarce vegetation El-wakil, et al. (2008) and considered the main breed dominates under the harsh conditions and food shortage prevailed in the north western coast of Egypt Elwakil et al. (2013). Many procedures have been used to enhance animal productivity such as feed additives to increase growth rate and milk production and enhancement animal health Nassar et al.( 2017). Feed additives are a group of nutrient and non-nutrient compounds which helps in improving the efficiency of feed utilization and thus reducing the high cost of feed. Karangiya et al (2016) Due to the growing popularity of the use of organic feed additives in feed production as a means of reducing production cost, enhancement of nutrients digestibility and body physiology Ogbuewu et al. (2014). The use of feed additives, such as ginger and garlic in livestock feed and human diets are becoming more popular, because of their beneficial health and preservative importance Manesh (2012).

The use of natural additives has reported as an essential principle of healthy nutrition. The ban on antibiotics use in animal nutrition as feed additives due to its residual effect found in milk and meat products and the increased awareness of the consumers about the health hazards occurs due to the use of antibiotics in animal nutrition triggered searching for natural and safe feed additives Khamisabadi et al. (2016). Ginger (Zingiber officinale) belongs to Zingiberaceae family; the part of the plant used is rhizome. Ginger is classified by the Food and Drug Administration as a safe food additive, which is regularly used for the ISSN: 2456-1878 https://dx.doi.org/10.22161/ijeab.53.30 treatment of asthma, diabetes, nausea, and pain in tropical countries. Elghandour et al (2018).

The plant produces an orchid like flower with petals that are greenish yellow streaked with purple color Polasa and Nirmala (2003).Ginger is a good source of essential micronutrients such as potassium, magnesium, copper, manganese and silicon, Potassium and manganese help to build resistance to disease and protect the lining of heart, blood vessels and urinary passages. Silicon promotes healthy skin, hair, teeth, and nails and helps to assimilate calcium. Small amount of vitamins A, E and some amounts of Bvitamins and Vitamin $\mathrm{C}$ are also found in ginger rhizome Adel and Prakash (2010).

The present study was carried out to evaluate the effects of additives ginger powder or oil as feed on, feed intake, digestibility, nitrogen and water utilization, ruminal fermentation and blood parameters of Barki sheep.

\section{MATERIALS AND METHODS}

\section{Animals and Treatments}

Experimental location: The current experiment was carried out in Maryout Research Station, Desert Research Center (DRC), Ministry of Agriculture and Land Reclamation, Egypt. This station located $35 \mathrm{~km}$ south of Alexandria governorate, Egypt.

\section{Animals and treatments:}

Digestibility trails: Four Barki rams of each group with an average live weight $(36.37 \pm 0.99 \mathrm{~kg})$ were individually kept and fed in metabolic cages to determine nutrient digestibility and nutritive value of the experimental rations. Also, nitrogen balance and water utilization were determined digestibility coefficients and feeding value. The digestibility trial was extended for 21 days as a preliminary period followed by 7 days as a collection period. All rams were fed on the same diets groups.

Feed intake and residuals were daily weighed and recorded during the collection periods, Total daily faces output was collected and $10 \%$ sample was taken and kept for later analysis. Faces and feeds were first dried at $65^{\circ} \mathrm{C}$ for 48 
hours and final dried were determined after drying in a forced air oven at $105^{\circ} \mathrm{C}$ for 3 hours. Dried samples were mixed and ground to pass through a $1.0 \mathrm{~mm}$ mesh screen for chemical composition. Total daily urinary excreted from each rams was collected in jar containing $100 \mathrm{ml}$ of $10 \%$ $\mathrm{H}_{2} \mathrm{SO}_{4}$ and $10 \%$ sample was taken and kept for later analysis. Samples of rumen liquid were taken $4 \mathrm{hrs}$ after feeding to estimate rumen $\mathrm{pH}$, ammonia nitrogen, volatile fatty acids concentrations and protozoa count.

Animals and rations: All experimental rams were feed offered was calculated to cover the maintenance requirements according to recommended by Kearl (1982). Roughage concentrate ratio was 40:60. Animal groups received one of four dietary treatments, $1^{\text {st }}$ group (G1) without any additives (Control). The $2^{\text {nd }}(\mathrm{G} 2)$ and $3^{\text {rd }}(\mathrm{G} 3)$ groups were additives (with 3 and 6 gm ginger powder (GP) /head/day), respectively. Ginger powder was mixed daily by concentrate mixture to offer for daily basis. The $4^{\text {st }}(\mathrm{G} 4)$ group was orally administered by (2 $\mathrm{ml}$ ginger oil (GO) / head/ day). Clean fresh water was offered twice daily.

Sampling and analysis of rumen liquor: at the end of the digestibility trail, rumen liquor samples were collected from animals during the digestibility trail by using a stomach tube at four hours post feeding. The rumen samples were filtered through two layers of cheese- cloth and $\mathrm{pH}$ values were recorded immediately by digital $\mathrm{pH}$-meter. Rumen samples were stored frozen $\left(-18^{\circ} \mathrm{C}\right)$ for later analysis. Samples of protozoa count were preserved and counted as described by the method of Dehority (1984).

Sampling and analysis of blood: on the last day of digestibility trail blood samples were taken randomly from rams. Then, centrifuged and separated blood serum was stored into a clean dried glass vial at $-20{ }^{\circ} \mathrm{C}$ for analysis. Biochemical analyses (total proteins, albumin, urea, creatinine, alanine transaminase (ALT), aspartate transaminase (AST), alkaline phosphatase (ALP), total lipids, and cholesterol) were measured in serum using kits provided by Diamond Company. Immunoglobulin (IgG) was measured by ELISA kits after serum dilution and according to Abbott Laboratories instruction (Abbotta Park, IL 60064 USA. Gamma-Glutamyl Transferrase (GGT) was determined by using kinetic colorimetric methods and commercial kits supplied by Spectrum-Diagnostics Egypt Company for Biotechnology. Lipid fraction in blood was assessed by measuring triglyceride concentration Hatch and Lees (1968) and Raltiff and Hall (1973).

Analytical Procedures: Proximate analyses of concentrate mixture and alfalfa hay Table (1) were carried out in Animal Nutrition Laboratory of Desert Research Center according to AOAC (2007). Neutral detergent fiber (NDF), acid detergent fiber (ADF) were determined by using the filter bag technique; ANKOM Technology Corp., Fairport, NY, USA. Fiber analyzer as described by Goering and Van Soest (1970).

Table 1. Chemical composition (\% on DM) of concentrate feed mixture (CFM) and alfalfa hay

\begin{tabular}{lccccccccc}
\hline Items & DM & OM & CP & EE & CF & NFE & Ash & NDF & ADF \\
\hline CFM & 92.95 & $\mathbf{8 8 . 3}$ & 16.25 & 2.2 & 14.3 & 55.55 & 11.7 & 42.7 & 21.3 \\
Alfalfa hay & 92.04 & 90.5 & 16.1 & 1.4 & 30.3 & 42.7 & 9.5 & 53 & 27.9 \\
\hline
\end{tabular}

$N D F=$ Neutral detergent fiber $; A D F=$ Acid detergent fiber

Ammonia nitrogen $\left(\mathrm{NH}_{3}-\mathrm{N}\right)$ in the rumen fluid was determined according to A.O.A.C. (2007). Total volatile fatty acids (TVFA's) were determined according to Warner (1964).

Statistical analysis: Data obtained in this study was statistically analyzed by one way of variances according to SAS (2004) using the following model; $Y_{i j}=\mu+T_{i}+e_{i j}$, Whers; $Y_{i j}=$ experimental observation, $\mu=$ overall mean, $T_{i}=$ effect of treatment, $e_{i j}=$ experimental error. Differences among means were compared by Duncan's multiple range Test of Duncan (1955).

\section{RESULTS AND DISCUSSION.}

\section{Feed intake and digestibility}

Feed intake: Data of feed intake, digestibility and nutritive value by Barki rams are presented in Table (2). The data indicated that the initial body weight was almost the same. Values of dry roughage intake, concentrate intake and total
DMI (g/ kg BW) were insignificant among the experimental groups. Because All Barki rams were fed restricted feeding on the same diets groups to cover their requirements of rams according to Kearl (1982) 
International Journal of Environment, Agriculture and Biotechnology, 5(3)

May-Jun, 2020 / Available: https://ijeab.com/

Table.2: Feed intake, digestibility and nutritive value of rams affected by tested rations during digestibility trial

\begin{tabular}{|c|c|c|c|c|c|}
\hline \multirow{2}{*}{ Items } & \multicolumn{4}{|c|}{ Experimental group } & \multirow{2}{*}{$\pm \mathrm{SE}$} \\
\hline & G1 & G2 & G3 & G4 & \\
\hline \multicolumn{6}{|l|}{ Roughage intake (DMI):- } \\
\hline$g / k g B W$ & 9.22 & 8.93 & 8.96 & 8.99 & 0.09 \\
\hline \multicolumn{6}{|l|}{ Concentrate intake (DMI):- } \\
\hline$g / k g B W$ & 11.67 & 11.78 & 11.82 & 11.80 & 0.15 \\
\hline \multicolumn{6}{|c|}{ Total Dry matter intake (TDMI):- } \\
\hline$g / k g B W$ & 20.89 & 20.71 & 20.78 & 20.79 & 0.21 \\
\hline \multicolumn{6}{|l|}{ Digestibility \%:- } \\
\hline DM & 61.29 & 62.42 & 60.71 & 64.33 & 0.64 \\
\hline $\mathbf{O M}$ & $65.04^{a b}$ & $66.00^{\mathrm{ab}}$ & $64.05^{b}$ & $67.77^{a}$ & 0. \\
\hline $\mathbf{C P}$ & $80.93^{b}$ & $80.56^{a b}$ & $\mathbf{7 9 . 0 3} 3^{\mathrm{b}}$ & $83.86^{\mathrm{a}}$ & \\
\hline $\mathbf{C F}$ & 48.19 & 52.37 & 49.56 & 53.06 & 1.07 \\
\hline NDF & 61.56 & 61.09 & 70.80 & 64.99 & 3.09 \\
\hline
\end{tabular}

Nutritive values

Total digestible nutrients, TDN

$\begin{array}{cccccc}g / k g B W & 13.53 & 13.57 & 13.27 & 14.02 & 0.18 \\ \text { TDN \% } & 64.72^{\text {ab }} & 65.59^{\text {ab }} & 63.83^{\text {b }} & 67.41^{\text {a }} & 0.56\end{array}$

Digestible crude protein, $\mathrm{DCP}$

$\begin{array}{cccccc}g / k g B W & 2.96 & 2.92 & 2.88 & 3.05 & 0.04 \\ \text { DCP \% } & 14.15^{\text {ab }} & 14.09^{\text {ab }} & 13.82^{\mathrm{b}} & 14.68^{\mathrm{a}} & 0.13\end{array}$

Means with different litters with each row are significantly different ( $\mathrm{P} \leq 0.05)$.(G1) concentrate feed mixture plus alfalfa hay without any additives (control) ; (G2) control ration adding with 3 gm ginger powder (GP) /head/day;(G3) control ration adding with 6 gm ginger powder (GP)/head/day;(G4) control ration adding with ginger oil (GO) $2 \mathrm{ml} /$ head/days oral.

Digestibility coefficients:

Data of digestibility indicated that the organic matter (OM) and crude protein $(\mathrm{CP})$ digestibility were high significantly $(\mathrm{P} \leq 0.05)$ for $\mathrm{G} 4$ than those recorded for $\mathrm{G} 2, \mathrm{G} 1$ and $\mathrm{G} 3$ groups. These results were in accordance with Soroor and Moeini (2015) who found that Ginger supplementation increased the IVOMD which is likely due to improvement of methane production. Digestibility of DM, CF and NDF were not affected $(\mathrm{P}>0.05)$ by the experimental diets. However, animals fed G4 had high insignificantly digestibility coefficients of DM and CF than other groups. Beneficial effects of herbs or botanicals in farm animals may arise from activation of feed intake and secretion of digestive secretions, immune stimulation, anti-bacterial, coccidiostatic, anthelmintic, antiviral or anti-inflammatory activity and antioxidant properties Kumar et al. (2014). However, Patra and Yu (2012) reported that clove, garlic, origanum, peppermint, or eucalyptus oil appeared to reduce feed digestibility differently. on the other hand El Essawy et al. $\left(\mathbf{2 0 1 9}^{\text {a }}\right)$ found that with ewes and they attributed this improvement in digestibility to the phenolic nature of eugenol and its potency in stimulating bacteria involved in feed digestion. Also El Essawy et al. $\left(\mathbf{2 0 1 9}^{\mathbf{b}}\right)$ found that Clove essential oils (EO) improved (DM), (OM), (CP), (EE), and $(\mathrm{ADF})$ digestibility $(\mathrm{P} \leq 0.05)$.

Nutritive values: Data of nutritive values indicated that G4 recorded high insignificantly TDN, DCP intake ( $\mathrm{g} / \mathrm{kg} \mathrm{BW})$, while recorded high significantly $(\mathrm{P} \leq 0.05) \mathrm{TDN}$ and $\mathrm{DCP} \%$ vs. those other group. It seems that the results of DM, TDN, DCP intakes and digestibility of $\mathrm{DM}, \mathrm{OM}, \mathrm{CP}$ and $\mathrm{CF}$ were reflected on nutritive values. Rams in $\mathrm{G} 4$ had higher $(\mathrm{P} \leq 0.05)$ value of TDN\% than other groups; mean values were $67.41,65.59,64.72$ and 63.83 $\%$ for G4, G2, and G1 and G3; respectively as that G4 (with ginger oil) 
had the high digestibility coefficient. On the other hand, $\mathrm{DCP} \%$ in G4 group was tended to be high than that recorded for G1, G2 and G3 (14.68 vs. 14.15, 14.09 and $13.82 \%$; respectively) as that $\mathrm{G} 4$ had the highest value of $\mathrm{CP}$ digestibility .The active components of ginger are reported to stimulate digestion, absorption, relieve constipation and flatulence by increasing muscular activity in the digestive tract Polasa and Nirmala (2003).

\section{Nitrogen utilization}

Nitrogen intake, excretion, and balance are presented in Table (3). Nitrogen intake ( $\mathrm{g} / \mathrm{kg} \mathrm{BW}$ ) was insignificantly affected by treated with ginger forms, because nutrient requirements were given (restricted feeding) as a results of body weight to cover maintenance requirements of rams according to kearl (1982)

Feacal nitrogen excretion as (g/ kg BW or \% of intake) was significantly $(\mathrm{P} \leq 0.05))$ affected by treatments, it seems that the value obtained from G3 with $6 \mathrm{gm}$ (GP) increased $(\mathrm{P} \leq 0.05)$ feacal nitrogen excretion more than other treatments, while; G4 (adding with ginger oil) had the lowest values of feacal nitrogen excretion. The values were $(0.123,0.113$, 0.110 and $0.093 \mathrm{~g} / \mathrm{kg} \mathrm{BW}$ ) for G3, G2, G1 and G4; respectively. This result may be duo to $\mathrm{G} 3$ was lowest value of digestibility $\mathrm{CP}$ while $\mathrm{G} 4$ was high digestibility of $\mathrm{CP}$ according table (2).

As for digested nitrogen ( $\mathrm{g} / \mathrm{kg} \mathrm{BW}$ ) the data were insignificant among experimental groups, it seems that G4 adding with ginger oil had the highest values $(0.49 \mathrm{~g} / \mathrm{kg}$ BW) of digested nitrogen, while it was significantly differed with digested nitrogen as a percentage of intake. It was interested to show that $\mathrm{G} 4$ had high significant $(\mathrm{P} \leq 0.05)$ value of digested nitrogen as a percentage of intake than other treatments, thus may be duo to G4 had the lowest values of feacal nitrogen excretion. While it was less than G3 (with 6 gm GP) in the values of digested nitrogen as \% of intake, thus duo to G3 had the highest values of feacal nitrogen excretion. Being value were 84.05, 81.03, 80.52 and78.90\% of intake for G4, G1, G2 and G3; respectively. Urine nitrogen excretion ( $\mathrm{g} / \mathrm{kg} \mathrm{BW}$ or $\%$ of intake) the data showed that were insignificant between experimental groups, it seems that G2 with 3 gm (GP) had the highest values of urine nitrogen excretion while G3 and G4 had the lowest and similar values of urine nitrogen excretion, while control group ( G1) had high value followed by G2. As for Total nitrogen execration as ( $\mathrm{g} / \mathrm{kg} \mathrm{BW}$ or $\%$ of intake) was significantly $(\mathrm{P} \leq 0.05)$ affected by treatments, it seems that the value obtained from G3 increased significant $(\mathrm{P} \leq 0.05)$

ISSN: 2456-1878

https://dx.doi.org/10.22161/ijeab.53.30 total nitrogen execration more than other treatments, while; G4 (adding with ginger oil) had the lowest values of total nitrogen execration. The values were $(0.143,0.140,0.133$ and $0.113 \mathrm{~g} / \mathrm{kg} \mathrm{BW}$ ) for G3, G2, G1and G4; respectively. As for total nitrogen excretion as percentage of intake, the values were $24.53,24.14,22.93$ and $19.38 \%$ of intake for G3, G2, G1 and G4; respectively. Generally, it was noticeable that treated with ginger powder forms in G3 and $\mathrm{G} 2$ increased total nitrogen excretion value compared to $\mathrm{G} 1$ and G4.

Nitrogen balance as ( $\mathrm{g} / \mathrm{kg} \mathrm{BW}$ or $\%$ of digested) was insignificant among the experimental groups, it seems that G4 (adding with ginger oil) had the highest values of nitrogen balance while $\mathrm{G} 2$ had the lowest values. As for nitrogen balance as percentage of digested nitrogen, the values were $95.65,95.11,95.10$ and $94.22 \%$ of digested for G3, G1, G4 and G2; respectively. It was interested to show that G4 had high significant $(\mathrm{P} \leq 0.05)$ value of nitrogen balance as a percentage of intake than other treatments, thus may be duo to G4 had the lowest values of feacal nitrogen excretion. While it was less than G3 in the values of nitrogen balance as a percentage of intake, being value were 79.93, 77.07, 75.86 and 75.47 for G4, G1, G2 and G3; respectively. This improvement in G4 (adding with ginger oil) was a result of less nitrogen excretion especially as fecal and urinary nitrogen which emphasized by improving the nitrogen balance. This result is in harmony with improved $\mathrm{CP}$ digestibility, DCP\%, and lower total $\mathrm{N}$ excretion, may be the direct result of protein protection against degradation in the rumen Newbold et al. (2004); Moreover ,improved efficiency of $\mathrm{N}$ metabolism in the rumen could reduce $\mathrm{N}$ losses in feces and urine Benchaar et al. (2008). Similarly, El-Essawy et al. (2019 ${ }^{\text {a }}$ found that nitrogen intake was not affected by essential oils (EO) supply while anise and clove EO supply reduced excreted nitrogen via feces compared with thyme EO and control Barkiewes, Nitrogen retention and nitrogen balance as \% of nitrogen intake were significantly increased by clove EO supply and the high nitrogen retention is resulted in response to lower nitrogen excretion and high nitrogen digestibility. Also, Dijkstra et al. (2013) explained that clove increased nitrogen retention due to the high level of active phenolic components. 
Table.3: Nitrogen utilization of experimental rations used to rams during digestibility trial

\begin{tabular}{|c|c|c|c|c|c|}
\hline \multirow{2}{*}{ Items } & \multicolumn{4}{|c|}{ Experimental group } & \multirow{2}{*}{$\pm \mathrm{SE}$} \\
\hline & G1 & G2 & G3 & G4 & \\
\hline \multicolumn{6}{|l|}{ Nitrogen intake:- } \\
\hline$g / k g B W$ & 0.580 & 0.580 & 0.583 & 0.583 & 0.006 \\
\hline \multicolumn{6}{|l|}{ Feacal nitrogen:- } \\
\hline$g / k g B W$ & $0.110^{a b}$ & $0.113^{a b}$ & $0.123^{a}$ & $0.093^{b}$ & 0.004 \\
\hline$\%$ of intake & $18.97^{a b}$ & $19.48^{\mathrm{ab}}$ & $21.10^{\mathrm{a}}$ & $15.95^{b}$ & 0.74 \\
\hline \multicolumn{6}{|l|}{ Digested nitrogen:- } \\
\hline$g / k g B W$ & 0.470 & 0.467 & 0.460 & 0.490 & 0.007 \\
\hline$\%$ of intake & $81.03^{a b}$ & $80.52^{\mathrm{ab}}$ & $78.90^{b}$ & $84.05^{\mathrm{a}}$ & 0.74 \\
\hline \multicolumn{6}{|l|}{ Urine nitrogen } \\
\hline$g / k g B W$ & 0.023 & 0.027 & 0.020 & 0.020 & 0.002 \\
\hline$\%$ of intake & 3.97 & 4.66 & 3.43 & 3.43 & 0.45 \\
\hline \multicolumn{6}{|c|}{ Total nitrogen execration:- } \\
\hline$g / k g B W$ & $0.133^{a b}$ & $0.140^{\mathrm{ab}}$ & $0.143^{a}$ & $0.113^{b}$ & 0.004 \\
\hline$\%$ of intake & $22.93^{a b}$ & $24.14^{\mathrm{ab}}$ & $24.53^{a}$ & $19.38^{b}$ & 0.81 \\
\hline \multicolumn{6}{|c|}{ Nitrogen balance ( retention):- } \\
\hline$g / k g B W$ & 0.447 & 0.440 & 0.440 & 0.466 & 0.007 \\
\hline$\%$ of intake & $77.07^{a b}$ & $75.86^{\mathrm{ab}}$ & $75.47^{b}$ & $79.93^{a}$ & 0.81 \\
\hline$\%$ of digested & 95.11 & 94.22 & 95.65 & 95.10 & 0.55 \\
\hline
\end{tabular}

Means with different litters with each row are significantly different $(\mathrm{P} \leq 0.05)$. (G1) concentrate feed mixture plus alfalfa hay without any additives(control) ; (G2) control ration adding with $3 \mathrm{gm}$ ginger powder (GP) /head/day; (G3) control ration adding with 6 gm ginger powder (GP) /head/day;(G4) control ration adding with ginger oil (GO) $2 \mathrm{ml} / \mathrm{head} /$ days oral .

\section{Water utilization}

The data of water utilization are presented in Tables (4), the data of water intake, water excretion and water balance showed insignificant difference among treatments. Animals fed control ration without any additives (G1) tended to increase free drinking water $(\mathrm{ml} / \mathrm{Kg} \mathrm{BW})$ more than all treatments (76.51), while, G2 was the second in free drinking water (74.77) and G3 was the third (69.75). While, G4 (adding ginger oil) take the lowest value (62.82). EL-Essawy et al. (2019) found that water intake consumed by animal groups were supply anise oil resulted in a significant reduction, differences in water intake could be attributed to different chemical structures of the studied ethanol oil, their contents from active components which affecting their actions and activities.

As for combined water $(\mathrm{ml} / \mathrm{Kg} \mathrm{BW})$, there was no significant difference between all treatments, while G4 take the high value (1.73). Also, there was no significant difference among treatments in metabolic water as $(\mathrm{ml} / \mathrm{Kg} \mathrm{BW})$, the data showed that total water intake $(\mathrm{ml} / \mathrm{Kg} \mathrm{BW})$ was high in $\mathrm{G} 1$ (control group) than other treatments, while the difference among groups were not significant, being value were 86.30, 84.59, 79.38 and 72.69 (ml/Kg BW) for G1, G2, G3 and G4; respectively. 
Table.4: Water consumption and balance of experimental rations used to rams during digestibility trial

\begin{tabular}{|c|c|c|c|c|c|}
\hline \multirow[t]{2}{*}{ Item } & \multicolumn{4}{|c|}{ Experimental group } & \multirow[t]{2}{*}{$\pm \mathrm{SE}$} \\
\hline & G1 & G2 & G3 & G4 & \\
\hline \multicolumn{6}{|l|}{ Water intake:- } \\
\hline \multicolumn{6}{|c|}{ Free drinking water:- } \\
\hline $\mathrm{ml} / \mathrm{Kg} B W$ & 76.51 & 74.77 & 69.75 & 62.82 & 2.33 \\
\hline \multicolumn{6}{|c|}{ Combined water:- } \\
\hline$m l / K g B W$ & 1.67 & 1.67 & 1.67 & 1.73 & 0.03 \\
\hline \multicolumn{6}{|c|}{ Metabolic water:-* } \\
\hline$m l / K g B W$ & 8.12 & 8.15 & 7.96 & 8.14 & 0.13 \\
\hline \multicolumn{6}{|c|}{ Total water intake:- } \\
\hline$m l / K g B W$ & 86.30 & 84.59 & 79.38 & 72.69 & 2.33 \\
\hline \multicolumn{6}{|c|}{ Water execration:- } \\
\hline \multicolumn{6}{|c|}{ Urinary water:- } \\
\hline$m l / K g B W$ & 37.32 & 38.73 & 34.37 & 38.31 & 2.43 \\
\hline$\%$ of intake & 43.31 & 45.36 & 43.30 & 52.70 & 2.53 \\
\hline \multicolumn{6}{|l|}{ Feacal water:- } \\
\hline $\mathrm{ml} / \mathrm{Kg} B W$ & 6.09 & 5.90 & 5.89 & 6.87 & 0.32 \\
\hline$\%$ of intake & 7.05 & 6.97 & 7.42 & 9.45 & 0.45 \\
\hline \multicolumn{6}{|c|}{ Total water execration } \\
\hline $\mathrm{ml} / \mathrm{Kg} B W$ & 43.41 & 44.63 & 40.25 & 45.17 & 2.37 \\
\hline$\%$ of intake & $\mathbf{5 0 . 3 0}$ & 52.76 & 50.71 & 62.14 & 2.50 \\
\hline \multicolumn{6}{|l|}{ Water balance:- } \\
\hline$m l / K g B W$ & $42.91^{\mathrm{a}}$ & $39.95^{\mathrm{ab}}$ & $39.13^{a b}$ & $27.52^{b}$ & 2.25 \\
\hline$\%$ of intake & 49.72 & 47.23 & 49.29 & 37.86 & 2.50 \\
\hline
\end{tabular}

*Metabolic water was calculated from TDN intake a yield of $0.6 \mathrm{~g}$. water per g. (Farid et al., 1986). Including insensible water loss.

Means with different litters with each row are significantly different $(\mathrm{P} \leq 0.05)$.(G1) concentrate feed mixture plus alfalfa hay without any additives(control); (G2) control ration adding with $3 \mathrm{gm}$ ginger powder (GP) /head/day;(G3) control ration adding with 6 gm ginger powder (GP) /head/day;(G4) control ration adding with ginger oil (GO) $2 \mathrm{ml} / \mathrm{head} /$ days oral.

The data of urinary water $(\mathrm{ml} / \mathrm{Kg} \mathrm{BW}$ or $\%$ of intake) indicated that was no significant difference between all treatments, G3 (adding with 6 gm GP) take the lowest value (34.37). While G4 increased urinary water (\% of intake) more than all treatments followed by G2, G1 and G3, being 52.70, 45.36, 43.31 and 43.30; respectively. Feacal water ( $\mathrm{ml} / \mathrm{Kg} \mathrm{BW})$ indicated that was no significant difference between all treatments, while G4 (adding with ginger oil) take the highest value (6.87). Also G4 increased Feacal water (\% of intake) more than all treatments followed by G3, G2 and G1, being 9.45, 7.42, 7.05 and 6.97; respectively. Ginger acts as a purgative, Fresh ginger helps to remove constipation while dry ginger powder is a fecal astringent, meaning it dries up the watery portion of the feces and causes constipation Malhotra et. al., (2003) . total excreted water ( $\mathrm{ml} / \mathrm{Kg} \mathrm{BW}$ or \% of intake) had the same trend, G4 (adding with ginger oil) had the highest value followed by G2, G3 while the lowest total excreted water was for G1 being 62.14, 52.76, 50.71 and $50.30 \%$ of intake.

The data indicated that water balance was slightly difference significantly $(\mathrm{P} \leq 0.05)$ among treatments; G1(without any additives) had the highest values of water balance as ( $\mathrm{ml} / \mathrm{Kg} \mathrm{BW}$ ) followed by G2,G3 while the lowest total water balance was for G4 (adding with ginger oil). It seems that group G1 (without any additives) had the highest values of water balance as a percentage of intake while G4 (adding with ginger oil) take the lowest, the values were $49.72,49.29,47.23$ and $37.86 \%$ of intake for G1, G3, G2 and G4; respectively. 


\section{Ruminal fermentation parameters:}

The effects of ginger either powder or oil additives on some rumen fermentation parameters are shown in Table (5). Data showed that $\mathrm{pH}$ value was within the normal range, which reflect that microbial digestion of fiber and protein Firkins (1996). Either ruminal $\mathrm{pH}$ levels or TVFA,s (meq/100 ml) concentration were not significantly affected by the experimental additives .The obtained results were in harmony with the finding of Kim et al.( 2012) reported that essential oils affects the rumen microbial activity and consequently alters ruminal fermentation. Also, Kholif et al. (2012) found no effect of adding garlic or ginger essential oils on ruminal $\mathrm{pH}$ of lactating goats. Furthermore, Ginger has strong antibacterial and to some extent antifungal properties. In vitro studies have shown that active constituents of ginger inhibit multiplication of colon bacteria Polasa and Nirmala (2003).

Total VFA concentration (TVFA,s (meq/100 ml)) was affected by ginger both powder or oil additives and insignificantly decreased in groups fed ginger both powder or oil compared with the control group, while G4 (with ginger oil) and G3(with 6 gm ginger powder) take the lowest values than for $\mathrm{G} 2$ and $\mathrm{G} 1$, The values were $6.40,6.17,5.80$ and 5.90 for G1, G2, G3 and G4 respectively. These results are in agreement with those reported by Zhang et al.( 2011) where total VFA concentration was decreased by the addition of ginger powder suggesting that the doses of ginger powder used modify diet fermentability. The obtained results were in harmony with the finding of Nassar et al.( 2017) reported that either ruminal $\mathrm{pH}$ levels or VFA concentration were not significantly affected by garlic either powder or oil additives. The use of ginger powder with antimicrobial activity would likely decrease microbial activity and diet fermentability may be due to that ginger increase stability of feed and beneficially influence the gastrointestinal ecosystem through inhibition of pathogenic microorganisms growth Srinivasan (2003)

Ammonia nitrogen was affected by ginger both powder or oil additives and significantly $(\mathrm{P} \leq 0.05)$ decreased in groups fed ginger both powder or oil compared with the control group, while G4 take the lowest values than for G2 and G3 which fed with ginger powder additives. The values were 22.13, 21.33, 17.97 and 16.90 for G1, G2, G3 and G4 respectively. These results are in agreement with those Soroor and Moeini (2015) found that NH3-N concentration linearly declined in the presence of ginger, total VFA concentrations were not influenced, but the acetate to propionate ratio declined and the branched fatty acids increased. However, there is limited ISSN: 2456-1878

https://dx.doi.org/10.22161/ijeab.53.30 information on the effect of ginger powder on ammonia-N concentration in the rumen; there was no significant difference in ammonia-N concentration Zhang et al. (2011). The reduction in ammonia- $\mathrm{N}$ concentration in treated groups may be due to inhibit protein hydrolyzing microorganism in the rumen Patra (2011).on the other hand Abu EL-Kassim et al. (2018) showed that ammonia- $\mathrm{N}$ concentration decreased significantly $(\mathrm{P}<0.05)$ in groups fed onion, garlic and fenugreek as compared with that fed control diet, with no significant differences among treated groups in the first, second and third month. Loss of energy takes place during ruminal fermentation because a considerable portion of consumed energy and protein is not utilized by microflora or host animal and thus is excreted as methane and ammonia nitrogen. Zhang et al. (2018). The same trend was found by Faniyi et al. (2016) they concluded that extracts of herbs and spices has a great potential in manipulating the process of rumen fermentation thereby reducing methane production, decreasing ammonium concentration and other rumen fermentation parameters. The same trend Nassar et al. (2017) reported that Ammonia nitrogen was affected by garlic supplement and significantly decreased in groups fed garlic oil (G3) compared with the control group.

With regard to Protozoa number, it is clear the redaction effect on ginger both powder or oil additives in microbial activities and insignificantly decreased in groups fed ginger both powder or oil compared with the control group, while G4 (with ginger oil) take the lowest values than for G2 and G3 which fed with ginger powder additives. The values were $3.27,3.37,3.70$ and 4.70 for G4, G2, G3 and G1, respectively. These results are in agreement with Kim et al (2012) who found that the supplementation of garlic and ginger extracts have decreased the protozoa population resulting in reduction of methane emission in the rumen and thus inhibiting methanogenesis and decreased the population of ciliate- associated methanogen, thereby, reducing methane emissions. Also The number of total protozoa, and the subfamilies Entodiniinae, and Diplodininane , were reduced by ginger treatment Soroor and Moeini (2015). Ruminal protozoa have a negative role on utilization of $\mathrm{N}$ by ruminants; Protozoa engulf and digest large numbers of ruminal bacteria thereby decreasing net microbial protein flow from the rumen to the duodenum Ivan et al. (2000). Similar results were found by Muhammad et al. (2016) showed that, the number of isolated organisms decreased with increasing level of ginger. It was observed that rumen bacterial specie composition decreased with increased ginger supplementation from $2.5 \mathrm{~g}$ ginger $/ \mathrm{kg}$. On the other 
hand, the ruminal methane production is abyproduct of the microbial digestive process and represents a loss of $2-12 \%$ of the feed energy. Furthermore, emission of methane is considered as one of the most important global environmental issues IPCC (2001). Furthermore, herbs and spices have been introduced also to ruminant nutrition. Microbial ecosystem in the rumen is composed from complex anaerobic microbial population of bacteria, fungi, protozoa, methanogeneous arhea and bacterifagi . Numerous metabolites produced in rumen during microbial fermentation affect the basic digestive and metabolic functions and productivity of the host Frankic et al. (2009) .

Table.5: Rumen parameters of experimental rations used to rams during digestibility trial

\begin{tabular}{|c|c|c|c|c|c|}
\hline \multirow{2}{*}{ Items } & \multicolumn{4}{|c|}{ Experimental group } & \multirow{2}{*}{$\pm \mathrm{SE}$} \\
\hline & G1 & G2 & G3 & G4 & \\
\hline pH & 6.97 & 7.22 & 7.10 & 6.99 & 0.23 \\
\hline TVFA,s (meq/100 ml) & 6.40 & 6.17 & 5.80 & 5.90 & 0.15 \\
\hline $\mathrm{NH}_{3}-\mathrm{N}$ (mg/100ml ) & $22.13^{a}$ & $21.33^{a b}$ & $17.97^{\mathrm{bc}}$ & $16.90^{c}$ & $\mathbf{0 . 8 3}$ \\
\hline $\operatorname{Protozoa}\left(X 1^{5}\right.$ cell $\left.^{\mathrm{ml}^{-1}}\right)$ & 4.70 & 3.37 & 3.70 & 3.27 & 0.36 \\
\hline
\end{tabular}

Means with different litters with each row are significantly different $(\mathrm{P} \leq 0.05)$.(G1) concentrate feed mixture plus alfalfa hay without any additives(control);(G2) control ration adding with 3 gm ginger powder (GP) /head/day;(G3) control ration adding with 6 gm ginger powder (GP) /head/day;(G4) control ration adding with ginger oil (GO) $2 \mathrm{ml} /$ head/days oral

\section{Blood parameters}

\section{Blood biochemical parameters}

Data in Table (6) indicated that Total protein and Albumin were insignificantly affected by additives with ginger either powder or oil while globulin, $\mathrm{A} / \mathrm{G}$ ratio and $\mathrm{IgG}$ were significantly $(\mathrm{P} \leq 0.05)$ affected by additives as compared to control group. Total proteins increased in G3 (adding with 6 gm (GP) /head/day) than other groups while G4 (adding with ginger oil $2 \mathrm{ml} / \mathrm{h} / \mathrm{d}$ ) showed the lowest value. The values were 8.12, 7.86, 7.42 and 6.62 for G3, G1, G2 and G4 respectively. May be due to that Ginger stimulates the flow of saliva, bile, and gastric secretions and therefore is traditionally used to stimulate appetite, reduce flatulence, colic, and gastrointestinal spasms, and generally act as a digestive aid Blumenthal et al. (2000). The lowest value of total proteins recorded via G4 (ginger oil addition), which might be attributed to that the essential oils modified the microbial population decreasing Protozoa count (X 10 $10^{5}$ cell $\mathrm{ml}^{-1}$ ) which is mainly responsible for protein degradation .

Table.6: Effect of tested rations on blood biochemical parameters of rams during digestibilit trail.

\begin{tabular}{|c|c|c|c|c|c|}
\hline \multirow{2}{*}{ Item } & \multicolumn{4}{|c|}{ Experimental group } & \multirow{2}{*}{$\pm \mathrm{SE}$} \\
\hline & G1 & G2 & G3 & G4 & \\
\hline Total protein (g/dl) & 7.86 & 7.42 & 8.12 & 6.62 & 0.38 \\
\hline Albumin (g/dl) & 4.23 & 4.65 & 4.60 & 4.99 & 0.14 \\
\hline Globulin (g/dl) & $3.61^{\mathrm{a}}$ & $2.76^{\mathrm{b}}$ & $4.05^{\mathrm{a}}$ & $1.48^{\mathrm{c}}$ & 0.31 \\
\hline A:G Ratio & $1.17^{\mathrm{b}}$ & $1.74^{\mathrm{b}}$ & $1.09^{\mathrm{b}}$ & $3.42^{\mathrm{a}}$ & 0.30 \\
\hline IgG* (IU/L) & $1.09^{\mathrm{b}}$ & $1.17^{\mathrm{b}}$ & $2.38^{\mathrm{a}}$ & $1.75^{\mathrm{ab}}$ & 0.20 \\
\hline
\end{tabular}

Means with different litters with each row are significantly different ( $\mathrm{P} \leq 0.05)$. (G1) concentrate feed mixture plus alfalfa hay without any additives (control);(G2) control ration adding with 3 gm ginger powder (GP) /head/day;(G3) control ration adding with 6 gm ginger powder (GP) /head/day;(G4) control ration adding with ginger oil (GO) $2 \mathrm{ml} / \mathrm{head} / \mathrm{days}$ oral.

*IgG: Immunoglobulin

However El-Essawy et al. (2019) who found that a significant reduction $(\mathrm{P}<0.01)$ in total protein $(\mathrm{TP})$ was resulted in ewes supplemented with clove and thyme supply ISSN: 2456-1878

https://dx.doi.org/10.22161/ijeab.53.30 but not with anise EO supply. This result agreed with Ferme et al. (2004) found that decreasing total proteins with adding ginger oil might be attributed to that the essential oils 
modified the microbial population profile, decreasing the contribution of Prevotella spp, which is mainly responsible for protein degradation and amino acids deamination suggesting a mode of action of essential oils on protein metabolism.

The values of albumin showed insignificant differences among groups (Table 6). The highest albumin value was in G4 (ginger oil addition), while the lowest value recorded by control group (G1). The values were 4.99, $4.65,4.60$ and 4.23 for G4, G2, G3 and G1 respectively. However, Khateri et al. (2017) recorded that total protein and albumin were not influenced by the added mixture of EO. Serum albumin values were increased with ginger either powder or oil, these results may be due to the improvements of ruminal microbial protein synthesis Kholif et al.(2012).Concerning globulin values, the results demonstrated that G3 had high $(\mathrm{P} \leq 0.05)$ globulin value than other groups. This result agreed with El- Essawy et al. $\left(\mathbf{2 0 1 9}^{\mathbf{b}}\right)$ found that decreasing globulin value with adding EO compared to control group. While Al-Saigh (2012) they reported that value of globulin was increased significantly in serum blood of local Iraqi black goat kids that fed ration contained $2.5 \%$ ginger roots as compared to control ration. Also total protein, globulin and blood glucose were significantly $(\mathrm{P} \leq 0.05)$ affected by supplementation with ginger root powder. Shams and Jarjeis (2015) globulin values were increased significantly with the ginger root powder supplementation. On the other hand, the lowest values of globulin were in G4. Similarly, El-Essawy et. al. $\left(\mathbf{2 0 1 9}^{\mathrm{a}}\right)$ showed that reduced levels of total protein $(\mathrm{P}<0.01)$ in ewes supplemented with clove and thyme EO consequently decreased levels of globulins.

Animals fed ginger either powder or oil additives had high IgG than control group. The highest value was recorded in G3 followed by G4 while the lowest value recorded for G1 (control group). The values were 2.38, $1.75,1.17$ and 1.09 for G3, G4, G2 and G1 respectively. In dairy cows that were fed ginger fine powder recorded increase in $\mathrm{RBCs}, \mathrm{Hb}, \mathrm{PCV}$, platelets, and WBCs than those fed basal diet only Shams and Jarjeis (2015). Also Hendawy et al (2019) found that Supplementation of black seed and ginger fine powder to ewes' diet may have a positive effect on blood hematology. Thus, they can be used to enhance the immune response of farm animals.

\section{Lipids profile.}

Total lipids $(\mathrm{mg} / \mathrm{dl})$ values showed significant $(\mathrm{P} \leq 0.05)$ increase in animals G4 (adding with ginger oil) There were no significant differences among other groups. The control group had high Total lipids (TLs) values than that of G2 and G3 (with 3 and 6 ginger powder additives).El-Essawy et al. (2019 $\left.{ }^{a}\right)$ showed that Clove and thyme EO supply were associated with hypocholesterolemic effect and high total lipids (TL) which reduced with anise EO supply total lipids (TL) and lipase activity were elevated with clove and thyme EO supply compared with other groups.

Table.7: Effect of tested rations on lipids profile of rams during digestibility trail.

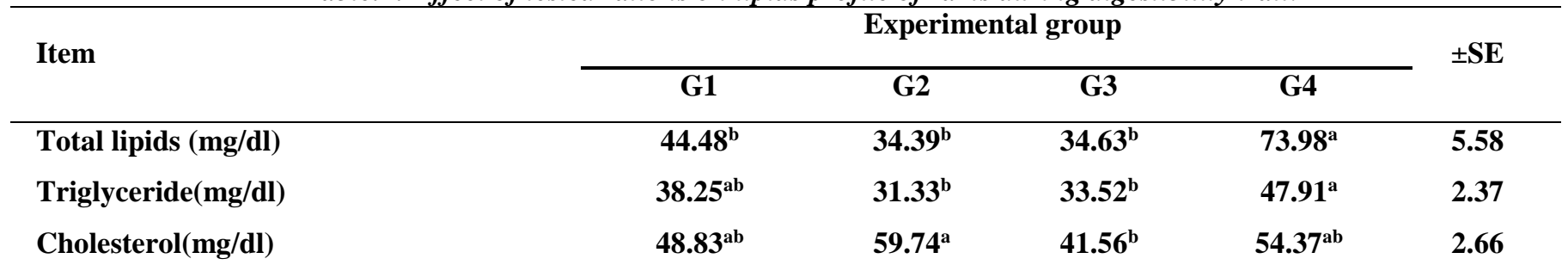

Means with different litters with each row are significantly different $(\mathrm{P} \leq 0.05)$.(G1) concentrate feed mixture plus alfalfa hay without any additives (control);(G2) control ration adding with $3 \mathrm{gm}$ ginger powder (GP)/head/day;(G3) control ration adding with 6 gm ginger powder (GP)/head/day;(G4) control ration adding with ginger oil (GO) $2 \mathrm{ml} / \mathrm{head} /$ days oral 
The values of triglyceride had the same trend of TLs where G4 (adding with ginger oil) had high $(\mathrm{P} \leq 0.05)$ triglyceride concentration than those for other groups. Moreover, control group (G1) also, insignificantly the concentrations of triglyceride of G2 and G3, as showed in Table (7). The reduction observed in triglyceride for both rations supplemented with ginger powder (G3 and G2) may be due to the influences of GP on liver tissues and benefit in metabolism and the negative effect of GO on rumen microflora activity and digestion (Abo Bakr 2019).

Animals fed ginger either powder or oil additives (G2 and G4) had high Cholesterol (mg/dl) than control group. The highest value was recorded in $\mathrm{G} 2$ followed by $\mathrm{G} 4$ while the lowest value recorded for G3 (with $6 \mathrm{gm} \mathrm{GP}$ ). The values were 59.74, 54.37, 48.83 and 41.56 for G2, G4, G1 and G3 respectively. Decreasing cholesterol in G3 may be due to high dosage of GP (Abo Bakr 2019). Similarly, El-Essawy et. al.(2019) showed that total lipids (TLs), low density lipoprotein (LDL) and total cholesterol (TC) were significantly increased $(\mathrm{P} \leq 0.05)$ in lambs given $\mathrm{EO}$ compared with control lambs, these reduced levels of total cholesterol may be attributed to the reduction in cholesterol synthesis. The same trend Nassar et al. (2017) cleared that triglycerides and cholesterol concentrations were significantly decreased in garlic as powder or oil additives compared to control groups. Medicinal herbs such as garlic and ginger have been reported to possess lipid lowering effects Agarwal (1996). Amethanolic extract of dried rhizomes of ginger produced a significant reduction in fructose-induced elevation of lipid levels, be achieved with a dietary supplement of either ginger or its extract containing aldose reductase inhibitors Kato et al (2006). On the other hand, Kholif et al. (2012) indicated that cholesterol concentration decreased significantly $(\mathrm{P}<0.05)$ in dairy goats supplementation garlic or ginger essential oils.

\section{Kidney and liver function}

Serum urea concentration decreased significantly $(\mathrm{P} \leq 0.05)$ in $\mathrm{G} 4$ (with ginger oil) and insignificant differences between G2 and G1 while G3 high than other groups Table (8). The values were 83.39, 79.51, 75.65 and 69.30 for G3, G1, G2 and G4 respectively. Decrease in urea concentration may be as a result of inhibition effect of ginger oil on deamination and lower ruminal ammonia concentration. The same trend Nassar et al. (2017) reported that decrease in urea concentration as a result of inhibition effect of garlic oil on deamination and lower ruminal ammonia concentration. Serum urea concentration decreased significantly with ginger oil additives (Abo Bakr 2019).

Table.8: Effect of tested rations on Kidney and liver function of rams during digestibility trail.

\begin{tabular}{|c|c|c|c|c|c|}
\hline \multirow{2}{*}{ Item } & \multicolumn{4}{|c|}{ Experimental group } & \multirow{2}{*}{$\pm \mathrm{SH}$} \\
\hline & G1 & $\overline{\text { G2 }}$ & $\overline{\text { G3 }}$ & G4 & \\
\hline Urea (mg/dl) & $79.51^{a b}$ & $75.65^{a b}$ & $83.39^{a}$ & $69.30^{b}$ & 2.07 \\
\hline Creatinine (mg/dl) & $1.87^{\mathrm{c}}$ & $2.40^{b}$ & $2.78^{\mathrm{a}}$ & $2.90^{\mathrm{a}}$ & 0.12 \\
\hline $\operatorname{ALT}(\mathbf{I U} / \mathbf{L})$ & $41.90^{c}$ & $50.43^{\mathrm{a}}$ & $48.70^{a b}$ & $\mathbf{4 7 . 4 3}^{\mathrm{b}}$ & 1.01 \\
\hline $\operatorname{AST}(\mathbf{I U} / \mathbf{L})$ & $63.30^{b}$ & $70.97^{a}$ & $71.43^{a}$ & $65.83^{b}$ & 1.11 \\
\hline ALP(IU/L) & 4.64 & 6.04 & 5.79 & 5.62 & 0.24 \\
\hline GGT(IU/L) & 25.49 & 27.73 & 29.81 & 29.79 & 0.79 \\
\hline
\end{tabular}

Means with different litters with each row are significantly different $(\mathrm{P} \leq 0.05)$.(G1) concentrate feed mixture plus alfalfa hay without any additives(control);(G2) control ration adding with $3 \mathrm{gm}$ ginger powder (GP)/head/day;(G3) control ration adding with 6 gm ginger powder (GP)/head/day;(G4) control ration adding with ginger oil (GO) $2 \mathrm{ml} / \mathrm{head} /$ days oral

ALT: Alanine Transaminase, AST: Aspartate Transaminase, ALP: Alkaline Phosphatase, GGT:Gamma-Glutamyl Transferrase

Control group (G1) recorded significant $(\mathrm{P} \leq 0.05)$ decrees for creatinine value (1.87) compared with the experimental groups Table (8) while G4 recorded high value of creatinine
(2.90) than other groups. Similarly, El-Essawy et al. (2019 $)$ showed that insignificant increasing in creatinine value for ewes which supplemented with Anise, clove and thyme EO comparison to control. 
The obtained results of ALT and AST activity in blood serum showed that there were significant $(\mathrm{P} \leq 0.05)$ decreases for G1 compared to other treated groups Table (8). while, ALP and GGT decrease insignificant for G1 for other groups. At all levels of ginger feeding $(0.5,1$ and 5\%) stimulation of glutathione-s-transferases (GST), activity was seen in liver and lungs whereas in intestine and kidney, a significant increase was observed at 1 and 5\% level of ginger feeding Polasa and Nirmala (2003). However, plasma levels of alanine aminotransferase (ALT) and aspartate aminotransferase (AST) were not influenced by addition of Essential oils. El-Essawy et. al. (2019 $\left.{ }^{\text {b }}\right)$

\section{REFERENCES}

1. A.O.A.C. (2007). Association of Official Analytical Chemists. Official Methods of analysis, $19^{\text {th }}$ Edition, Washington, USA.

2. Abo Bakr, S., (2019). Effect of adding ginger powder or ginger oil on productive performance of ewes during lactation period. Egyptian J. Nutrition and Feeds 22(1): 63-78.

3. Abu EL-Kassim, M.A.; Abd El-Hafez, G.A., Mousa,S.M. and Hassan, E.H., (2018). Effect of Dietary Onion, Garlic and Fenugreek Seeds Powder on Feed Intake, Blood Metabolites and Rumen Fermentation in Ossimi Ewes. Assiut J.Agric. Sci., (49) No. (2) :(38-48).

4. Adel, S. P. R. and Prakash, J., (2010). Chemical composition and antioxidant properties of ginger root (Zingiber officinale), Journal of Medicinal Plants Research, 4(24):2674-2679.

5. Agarwal, K.C., (1996). Therapeutic actions of garlic constituents. Med. Res., 16: 111-124.

6. Al-Saigh,M.N, and Hadi,L.E., (2012).The synergistic effect of zingiber officinale roots and vitamin $\mathrm{E}$ on some reproductivity and physiological traits in ratios of kid Iraqi black goat .Tikrit J.Agri.Sci., 12(2):21-34.

7. Bakry, E. A.,Metawi, H. R.,El-Sherbiny, A. M., Abd-Elrazek, M. K., El-Eraky, M. B., and Ali, A. M., (2018) performance of Barki sheep production under climate change conditions in Egypt. J. Environ. Sci. Institute of Environmental Studies and Research Ain Shams University. Vol.41, No.1.

8. Benchaar, C., Calsamiglia, .S., Chaves A.V. , Fraser G.R.,Colombatto D., McAllister T.A. , Beauchemin K.A. (2008). A review of plant-derived essential oils in ruminant nutrition and production, Animal Feed Science and Technology 145 : 209-228 .

\section{CONCLUSION}

In conclusion, ginger both powder or oil additives to ration of Barki rams had beneficial effects on digestibility coefficients, Nitrogen and water balance, Ruminal fermentation and some blood biochemical parameters, ginger had positive effects on blood parameters, improve the immunity of animals, Further research is needed to study effects of the mechanism of action ginger additives on digestibility, rumen and blood parameters.

9. Blumenthal M, Goldberg A, Brinckmann J, (2000). Herbal Medicine: Expanded Commission E Monographs. (Integrative Medicine Communications, Boston).

10. Dehority, B. A. (1984). Evaluation of sub-sampling and fixation procedures used for counting rumen protozoa. Applied Environment Microbiology, 48: 182185.

11. Dijkstra, J., Oenema, O., van Groenigen, J. W., Spek, J. W., van Vuuren, A. M., \& Bannink, A. (2013). Diet effects on urine composition of cattle and N20 emissions. Animal, 7(S2), 292-302.

12. Duncan, D.B., (1955). Multiple range and multiple Ftest. Biometris; 11: 1-42.

13. El-Essawy M. Abeer., Abdou R.Ahlam, Khattab I.M, and Abdel-Wahed A.M, (2019). Effect of addition of anise, clove and thyme essential oils on barki lambs performance, digestibility, rumen fermentation, carcass characteristics and intramuscular fatty acids. Egyptian J. Nutrition and Feeds, 22 (3): 465-487

14. El-Essawy, M. Abeer, Abdou, R. Ahlam; El-Gendy, H. Marwa. (2019). Impact of Anise, Clove and Thyme essential oils as feed supplements on the productive performance and digestion of Barki ewes.Australian J. of Basic and Applied Science., 13(1): 1-13.

15. Elghandour, M. M. M. Y., Kanth Reddy, P. R., Salem, A. Z. M., Ranga Reddy, P. P., Hyder, I., Barbabosa-Pliego, A., and Yasaswini, D., (2018). Plant Bioactives and Extracts as Feed Additives in Horse Nutrition. Journal of Equine Veterinary Science, 69, 66-77.

16. El-Wakil, Salwa., and Elsayed, Manal.,

(2013) 
.Genetic, Phenotypic And Environmental Trends Towards Improving Body Weight In Barki Sheep . Egyptian Journal of Sheep \& Goat Sciences, Vol. 8 (2), P: 11- 20.

17. El-Wakil, Salwa, I., Shemeis, A.R., Ahmed, A.M. and Abdallah, O.Y. (2008). Genetic and phenotypic relationships involving body weight, degree of maturity and measurer of gain rate of Barki sheep without having recourse to fitting growth curves .J. Agric .Sci. Mansoura Univ., 33: 4835-4848.

18. Faniyi,T.O., Prates, E.R.,Adewumi, M.K., and Bankole, T. (2016) . Assessment of herbs and spices extracts/meal on rumen fermentation: Review. Pubvet, ai.,(10),5: 427-438

19. Ferme, D., Banjac, M., Calsamiglia, S., Busquet, M., Kamel, C., and Avgustin, G., (2004). The effects of plant extracts on microbial community structure in a rumen-simulating continuous-culture system as revealed by molecular profiling. Folia Microbiol (Praha) 49: 151-155.

20. Firkins, J.L., (1996). Maximizing microbial protein synthesis in the rumen. The Journal of Nutrition, 126, 1347-1354.

21. Frankic, T., Voljg, M., Salobir, J., Rezar, V., (2009). Use of Herbs and spices and their extracts in animal nutrition. Acta Agriculturae Slovenica, 92(2): 95-102.

22. Goering, H.K., Van Soest, P.J., (1970). Forage Fiber Analyses. Agriculture Handbook No: 379. Washington, DC, USA: ARSUSDA.

23. Hatch, F.T., and Lees, R.S., (1968). Practical methods for plasma lipoprotein analysis. Advances in Lipid Research; 6; 1-68.

24. Hendawy, A.O., Mansour M.M., Nour El-Din, A.N.M.,(2019) Effects of medicinal plants on haematological indices, colostrum, and milk composition of ewes. J Vet Med Animal Sci. 2(1): 1008.

25. I.P.C.C., (2001). In: Houghton, J.T. et al. (Eds.), Climate Change 2001: The Scientific Background, vol. 94. Cambridge University Press, Cambridge, UK.

26. Ivan, M., Neill, L., Forster, R., Alimon, R., Rode, L.M., Entz, T., (2000). Effects of Isotricha, Dasytricha, Entodinium, and total fauna on ruminal fermentation and duodenal flow in wethers fed different diets. J. Dairy Sci. 83,776-787.

27. Karangiya, V. K., Savsani, H. H. , Patil, S. S., Garg, D. D., Murthy, K. S., Ribadiya, N. K., and Vekariya, S. J.,(2016). Effect of dietary supplementation of garlic, ginger and their combination on feed intake, growth performance and economics in commercial broilers. Veterinary World, EISSN: 22310916 Availabl at ww.veterinaryworld.org/Vol.9/March2016/4.pdf.

28. Kato, A., Higuchi, Y., Goto, H., Kizu, H., Okamoto, T., Asano, N., Hollinshead, J,, Nash, R.J., and Adachi, I., (2006). Inhibitory effects of Zingiber officinale Roscoe derived components on aldose reductase activity in vitro and in vivo. J. Agric. Food Chem, 54: 6640-6644,

29. Kearl, L. C., (1982). Nutrients requirements in developing countries. International Feedstuffs Institute Utah Agric. Exp. Stat.; Utah State University, Logan; USA.

30. Khamisabadi, H., Kafilzadeh, F., and Charaien, B., (2016). Effect of thyme (Thymus vulgaris) or peppermint (Mentha piperita) on performance, digestibility and blood metabolites of fattening Sanjabi lambs. J. Biharean biologist., 10 (2): 118-122.

31. Khateri, N., Azizi, O., and Jahani-Azizabadi, H., (2017). Effects of a specific blend of essential oils on apparent nutrient digestion,rumen fermentation and rumen microbial populations in sheep fed a 50:50 alfalfa hay:concentrate diet. Asian-Australas J Anim Sci Vol. 30, No. 3:370-378.

32. Kholif, S. M., Morsy,T.A., Abdo, M.M., Matloup,O.H. and Abu ElElla, A.A., (2012). Effect of Supplementing Lactating Goats Rations with Garlic, Cinnamon or Ginger Oils on Milk Yield, Milk Composition and Milk Fatty Acids Profile. J Life Sci, 4:1, 27-34.

33. Kim, E., Kim, C.H., Min, K.S. and Lee, S., (2012). Effects of plant extracts on microbial population, methane emission and ruminal fermentation characteristics in in vitro. AsianAustralasian Journal of Animal Sciences, 25, 806-811.

34. Kumar, M., Kumar V.,, Roy, D., Kushwaha, R., Vaiswani S., (2014) Application of Herbal Feed Additives in Animal Nutrition - A Review. International Journal of Livestock Research. Vol 4(9)

35. Malhotra. S., and Singh A.P., (2003). Medicinal properties of ginger (Zingiber officinale oscoe).Natural Products Radiance.26: 296-300.

36. Manesh, M.K., (2012). Influence of poly germander and watercress extract on performance, carcass quality and blood metabolite of male broilers. Res Opinions in Anim. and Vet. Sci. 2: $69-71$.

37. Muhammad. N., Ibrahim, U. M., Maigandi, S. A., 
and Abubakar, I. A., (2016). Live Performance and Rumen Microbial Composition of Yankasa Rams with Supplemented Levels of Zingiber officinale . Journal of Agriculture and Ecology Research International 8(4): $1-10$.

38. Nassar, M. S., Afaf El Shereef, and Abo Bakr, S., (2017). Influence of feeding garlic plant either as powder or oil on reproductive performance of ewes. GSC Biological and Pharmaceutical Sci., 1(3):59-61.

39. Newbold, C.J., McIntosh, F.M., Williams, P., Losa, R., and Wallace, R.J., (2004). Effects of a specific blend of essential oil compounds on rumen fermentation. Anim. Feed Sci. Technol., 114: 105-112.

40. Ogbuewu I.P., Jiwuba, P.D., Ezeokeke, C.T., Uchegbu, M.C., Okoli I.C., and Iloeje, M.U., (2014) Evaluation of phytochemical and nutritional composition of ginger rhizome powder . Int'l journal of agric. And rural dev. Volume 17 (1): 1663-1670.

41. Patra, A. K., (2011). Effects of essential oils on rumen fermentation, microbial ecology and ruminant production. Asian. J. of Anim Vet. Adva, 6: 416-428.

42. Patra, A.K., and Yu, Z., (2012). Effects of Essential Oils on Methane Production and Fermentation by, and Abundance and Diversity of, Rumen Microbial Populations. Applied and Environmental Microbiology. 78: 12, P.4271-4280

43. Polasa, K., and Nirmala, K., (2003). Ginger: Its role in xenobiotic metabolism. ICMR Bulletin 33:56-62

44. Raltiff ,C.R., and Hall, F., (1973). Laborator y Manual of Clinical Biochemistry. Temple; TX; Scott and Memorial Hospital Publication Office.
45. S.A.S., (2004). Statistical Analysis System; STAT/ user's guide; Release 9.1; SAS Institute; Cary NC. USA.

46. Shams Al-dain, Q.Z., and Jarjeis, E. A., (2015) Vital impact of using ginger roots powder as feed additive to the rations of local Friesian dairy cows and its effect on production \& economic efficiency of milk and physiological of blood . Kufa Journal for Veterinary Medical Sciences Vol. (6) No. (1).

47. Soroor, M. E. N., and Moeini M. M., (2015). The Influence of Ginger (Zingiber Officinale) on In vitro Rumen Fermentation Patterns. Annual Research \&Review in Biology. 5(1): 54-63.

48. Srinivasan,V., Hamza,S., Murithy, K., and Thankamani,C., (2003).Threshold. Level of soil zinc for optimum production of ginger (Zingiber officinale Rosc).National Seminar new perspectives in spices plants. Medicinal and Aromatic.,69-70.

49. Warner, A.C.I., (1964). Production of volatile fatty acids in the rumen, Method of measurement. Nutr. Abstract and Review, 34: 339.

50. Zhang, T. T., Yang, Z. B., Yang, W. R., Jiang, S. Z., and Zhang, G. G., (2011). Effects of dose and adaptation time of ginger root (Zingiber officinale) on rumen fermentation. J. Anim. Feed Sci. 20:461-471.

51. Zhang, Z.W., Cao, Z.J., Wang, Y.L., Wang, Y.J., Yang, H.J., Li S.L., (2018) Nitro compounds as potential methanogenic inhibitors in ruminant animals: A review. Anim. Feed Sci. Technol. 2018; 236: 107114. 